\title{
EWSR1/ZNF444 Fusion Protein
}

National Cancer Institute

\section{Source}

National Cancer Institute. EWSR1/ZNF444 Fusion Protein. NCI Thesaurus. Code C139732.

A fusion protein encoded by the EWSR1/ZNF444 fusion gene. This protein is comprised of the transactivation domain of the RNA-binding protein EWS fused to the last six Cterminal amino acids of zinc finger protein 444. 